\title{
Generalist populations formed by generalist individuals: a case of study on the feeding habits of a Neotropical stream fish
}

Populações generalistas formadas por indivíduos generalistas: um caso de estudo sobre os hábitos alimentares de um peixe de riacho Neotropical

Rafaela Carvalho Neves ${ }^{1}$ (D), Pedro Paulino Borges ${ }^{1}$ (D), Jaquelini de Oliveira Zeni² (D), Lilian Casatti ${ }^{3}$ (D) and Fabrício Barreto Teresa ${ }^{1 *}$ (D)

${ }^{1}$ Laboratório de Biogeografia e Ecologia Aquática, Universidade Estadual de Goiás - UEG, Anápolis, GO, Brasil

${ }^{2}$ Laboratório de Ecologia Aquática, Universidade do Estado de Minas Gerais - UEMG, Passos, MG, Brasil

${ }^{3}$ Laboratório de Ictiologia, Universidade Estadual Paulista “Júlio de Mesquita Filho”, São José do Rio Preto, SP, Brasil

*e-mail: fabricioteresa@yahoo.com.br

Cite as: Neves, R.C. et al. Generalist populations formed by generalist individuals: a case of study on the feeding habits of a Neotropical stream fish. Acta Limnologica Brasiliensia, 2021, vol. 33, e21.

Abstract: Aim: We described the diet of the generalist stream fish Knodus chapadae and we tested if the environmental conditions are associated with population's diet and individual specialization. Methods: We analyzed the stomach contents of 287 individuals from 29 streams from the Brazilian savanna (Cerrado). Results: The instream physical habitat structure, physiochemical conditions, and adjacent land use explained partially the variation in the diet of populations, but not the variation in the individual specialization. Thus, the diet changes observed at populational level were driven by changes in the average composition of the diet of individuals that, in turn, remained generalists along the environmental gradient. Conclusions: Our results show that the trophic opportunism described for small characids was also observed in K. chapadae, whose diet shifts according to changes in environmental conditions. Furthermore, the opportunism expressed at the individual level can explain the trophic plasticity observed on the studied species.

Keywords: Characidae; diet; intraspecific variation; individual specialization; trophic niche.

Resumo: Objetivo: Descrevemos a dieta do peixe de riacho generalista, Knodus chapadae, e testamos se as condições ambientais explicam a dieta das populaçôes e a especialização individual. Métodos: Para isso, analisamos o conteúdo estomacal de 287 indivíduos de 29 riachos da savana brasileira (Cerrado). Resultados: As variáveis da estrutura interna do hábitat, condiçōes físico-químicas e o uso do solo explicaram parcialmente a variação na dieta das populaçóes, mas nấo explicaram a variação na especialização individual. Então, as mudanças na dieta observadas no nível populacional foram decorrentes da mudança na composição média da dieta dos indivíduos que, por sua vez, permaneceram generalistas ao longo do gradiente ambiental. Conclusóes: Nossos resultados mostram que o oportunismo trófico descrito para pequenos caracídeos foi encontrado também em K. chapadae, cuja dieta muda de acordo com as características ambientais. Além disso, o oportunismo expresso em nível individual pode explicar a plasticidade trófica que é observada na espécie estudada.

Palavras-chave: Characidae; dieta; variação intraespecífica; especialização individual; nicho trófico. 


\section{Introduction}

Trophic variation in fish assemblages along environmental gradients is driven by species' turnover with different trophic specialization (Gonçalves et al., 2018) and by changes in the diet of species that persist along the gradient (Ferreira et al., 2012). This latter process involves generalist species that exhibit phenotypic plasticity to deal with distinct environmental conditions and differences in resource availability (Bojsen, 2005). These generalist species may change their diet (i.e., intraspecific variability) by exploring food items that become highly available (Ferreira et al., 2012). Most studies describing changes in species' diet assume that individuals niche is not variable and identical to the population niche, using diet average data as a descriptor of trophic niche from averaging individual diet data among all individuals of each population (e.g. Gonçalves et al., 2018). However, generalist populations may be formed by specialist individuals and high niche segregation, or by generalist individuals with high niche overlap (Araújo et al., 2011; Costa-Pereira et al., 2017; Liang et al., 2020; Xia et al., 2020). Therefore, assessing individual variability in diet can contribute to reveal intrapopulation mechanisms that explain species' niche patterns (Roughgarden, 1972; Bolnick et al., 2011).

Growing evidence from the literature indicates that individuals' niches tend to be narrower than the population niche (i.e., individual specialization) (Araújo et al., 2011). Several factors can influence the degree of individual specialization, such as phenotypic differences, effects of inter and intraspecific competition, and environmental context (Svanbäck \& Bolnick, 2007; Araújo et al., 2011; Cunha et al., 2018). In a context of intense intraspecific competition, for example, due to low food supply or high competitor's abundance, individuals may escape of conspecific competitors by shifting their niche, resulting in greater individual specialization (Svanbäck \& Persson, 2004). An opposite pattern may emerge when competition is relaxed (e.g. increasing resource supply) and individuals may share the most beneficial food resources, resulting in higher niche overlapping among them (Svanbäck \& Bolnick, 2005; Araújo et al., 2011). Some studies have also explored how individual specialization can vary across environmental gradients in response to resource availability fluctuations (i.e., ecological opportunity), consequence of the habitat changes (Quevedo et al., 2009; Darimont et al., 2009;
Murray \& Wolf, 2013). For example, environmental heterogeneity may increase niche segregation among individuals by offering a greater diversity of resources (Darimont et al., 2009). In this scenario, individual specialization would be higher and could favor the most efficient use of available resources and conditions by individuals.

Streams draining agroecosystems exhibit a broad range of environmental conditions, depending on the level of anthropogenic changes in their catchment (Leal et al., 2016). More conserved streams tend to receive frequent input of food resources from riparian vegetation, such as allochthonous invertebrates and vegetal matter (fruits, seeds, and flowers) (Chan et al., 2008). Furthermore, wood debris and other structures from the riparian vegetation also contribute to establishment of algae and macroinvertebrates and detritus accumulation (Angermeier \& Karr, 1984; Flores et al., 2011; Ceneviva-Bastos et al., 2017). In contrast, more degraded streams tend to exhibit more homogeneous habitat structure and food resources availability (Lorion \& Kennedy, 2009; Zeni \& Casatti, 2014). Therefore, given its higher environmental complexity and diversity of food supply, conserved streams could provide greater ecological opportunity for individual specialization than more degraded ones.

Many Neotropical fish species may be found along the entire gradient of environmental conditions of streams. These species are known by their trophic plasticity, using a broad set of food resources (Lowe-McConnell, 1987; Mortillaro et al., 2015; Gelwick \& McIntyre, 2017). Characidae small tetras are good examples of species with high trophic plasticity, since they are usually classified as omnivorous species and they are able to change their diet according to environmental conditions (Ferreira et al., 2012; Manna et al., 2019). Individuals of these species may employ different behavioral tactics and explore the majority of the microhabitats available in the streams (Ceneviva-Bastos \& Casatti, 2007). However, whether and how intrapopulation mechanisms drive the diet changes of these generalist fish along environmental gradients remains to be tested.

Here, we investigated the trophic ecology of the small-sized tetra, Knodus chapadae (Fowler, 1906), in streams from agroecosystems in Brazilian savanna (Cerrado). This species is dominant at the AraguaiaTocantins ecoregion occurring in a wide range of environmental conditions (Barbosa et al., 2019). Specifically, we asked the following questions: i) 
How does the diet of the generalist species, Knodus chapadae, vary according to the environmental conditions in streams? ii) Does the variation in trophic individual specialization among populations is explained by environmental conditions? Our first hypothesis is that diet of the populations varies along the gradient of environmental conditions due the shift in the diversity and composition of available food resources. To test this hypothesis, we used the classical approach that consists in describing population trophic patterns by averaging individual diet data of each population. Regarding the second question, we expect that more conserved streams, with greater environmental complexity can present greater diversity of food resources (Lorion $\&$ Kennedy, 2009), which provides an opportunity for trophic niche segregation among individuals (ecological opportunity) (Murray \& Wolf, 2013) with higher individual specialization.

\section{Material and Methods}

\subsection{Study area}

We sampled Knodus chapadae individuals in 29 streams sites from first to third order (Strahler, 1957), located in the Upper Tocantins river basin, Araguaia-Tocantins ecoregion (sensu Abell et al., 2008) (Figure 1), which is included in the Brazilian savanna (Cerrado) biome. Sampled sites encompassed the regional gradient of environmental conditions varying from less-disturbed forested streams to high-disturbed streams with narrow or absent riparian forest (Barbosa et al., 2019). The climate is tropical, with a wet season from October to April and a dry season from May to September (Bustamante et al., 2012). The sampling sites have altitudes ranging from 392 to $563 \mathrm{~m}$ and slopes of $11 \%$ to $32 \%$ (Borges et al., 2016). Detailed information of the study region may be assessed in Borges et al. (2016) and Barbosa et al. (2019).

\subsection{Fish sampling and diet analysis}

We conducted the fish sampling during the dry season, in 80-meters reaches in each stream, with a standardized electrofishing single pass (about 150 min of sampling effort), using an alternating current generator (1,000 W, 300-500 V, 1-3 A) (Mazzoni et al., 2000). Fish were fixed in $10 \%$ formaldehyde solution and transferred to a $70 \%$ alcohol solution 72 hours after samplings. Fish had their taxonomic identification confirmed by specialists (Dr. Fernando Rogério Carvalho, Universidade Federal do Mato Grosso do Sul, Brazil). Voucher specimens are deposited in the Fish Collection of the Zoology and Botany Department (DZSJRP, voucher 20225), in the São Paulo State University "Júlio de Mesquita Filho", São

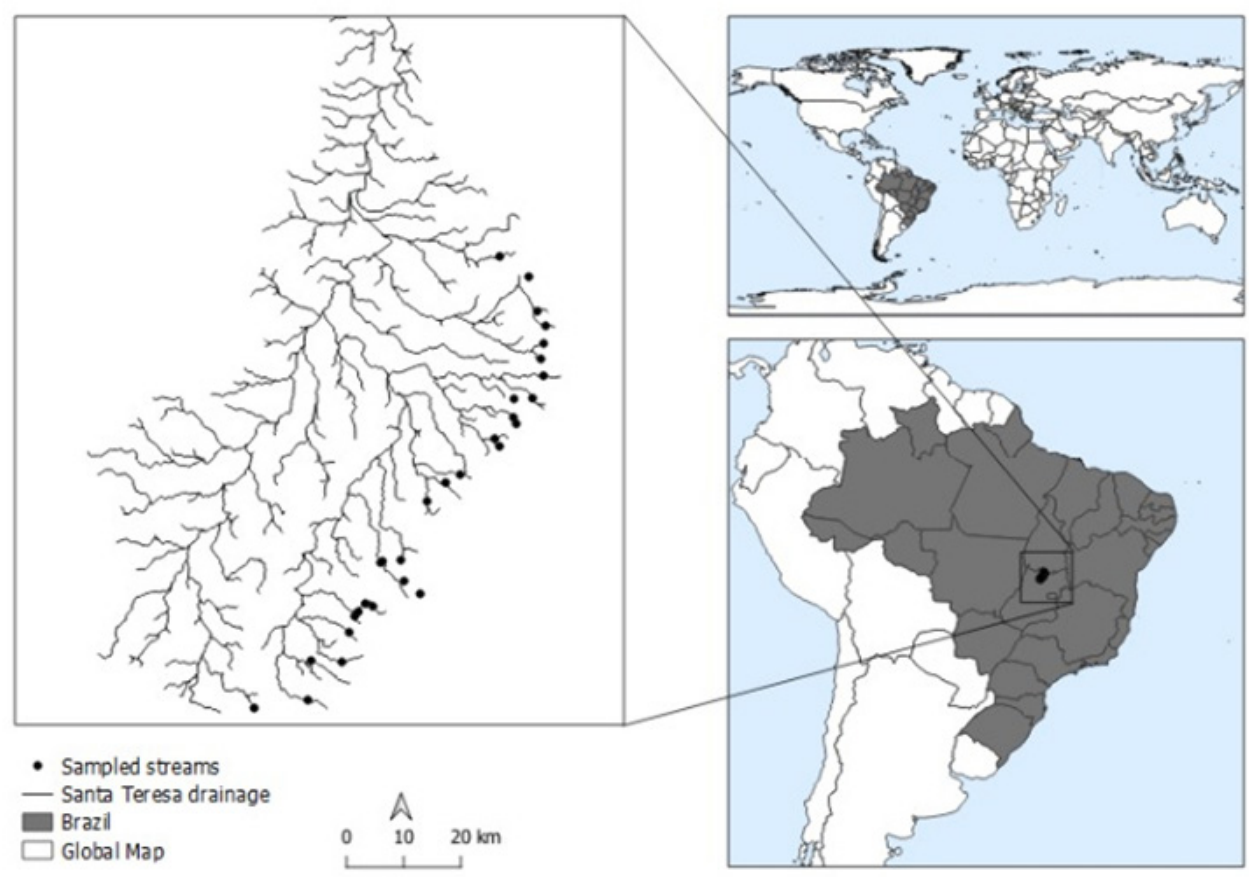

Figure 1. Location of the study area, showing the sampled low-order streams in the upper Tocantins river basin, north of Goiás state, Brazil. 
José do Rio Preto, São Paulo State, Brazil. Fishes were collected with permission from the Instituto Brasileiro do Meio Ambiente e dos Recursos Naturais Renováveis (IBAMA license \# 34144-1).

We assessed the diet of ten individuals in each stream site, except in two sites where we assessed eight and nine individuals, totaling 287 individuals. We tried to select the largest individuals of each site for diet analysis, in order to minimize the influence of ontogenetic variation in the diet (standard length \pm standard deviation $=6.2 \pm 0.7 \mathrm{~cm}$ ). We accessed each stomach by doing a ventral incision and, subsequently, we identified the food items to the lowest possible taxonomic level (Mugnai et al., 2010) and quantified using stereomicroscope and optical microscope. We grouped the food items into five categories: (1) aquatic invertebrates, which include larval insects, such as Diptera (mosquitoes and flies), Ephemeroptera (mayflies), Odonata (dragonflies and damselflies), Trichoptera (caddisflies), Plecoptera (stoneflies), Lepidoptera (moths) and Hemiptera (bedbugs); (2) terrestrial invertebrates, which include adults of Coleoptera (beetles), Hymenoptera (wasps, bees and ants), Diptera, Isoptera (termites), Hemiptera, Lepidotera (butterflies and moths), Psocoptera, and Pseudoscorpiones; (3) filamentous algae; (4) vegetal matter (seeds, leaves, flowers, root); and (5) detritus. We obtained the percentage composition of the items in each stomach by visually estimating the volume occupied by each food item considering all the items volume. We calculated an adapted version of the Feeding Index (IA $)$, which indicates the importance of each item in the diet of the population (Kawakami \& Vazzoler, 1980), according to the formula: $I A_{i}=O_{i} \cdot D_{i} / \sum\left(O_{i} \cdot D_{i}\right)$, where, $\mathrm{Oi}$ is the proportional number of stomachs in which item $i$ occurred in a given population, and $\mathrm{Di}$ is the proportion of stomachs in which item $\mathrm{i}$ was dominant (most representative item among all items of individuals analyzed) in a given population.

\subsection{Individual specialization}

We described individual specialization for each population (set of individuals from each stream) by using two metrics. The first metric was the Proportional Similarity Index (PS) that quantifies possible differences in individual resource exploitation (Bolnick et al., 2002), as follows: $P S_{i}=1-0.5 \sum_{j}\left|p_{i j}-q_{j}\right|=\sum_{j} \min \left(p_{i j}, q_{j}\right)$, where, pij describes the proportion of item $j$ in the diet of individual $\mathrm{i}$; and $\mathrm{qj}$ is the proportion of use of resource $\mathrm{j}$ in the population. Values close to 1 indicate that individuals consume resources in the same way as the population, and values close to 0 indicate that individuals consume resources differently from the population as a whole. Individual specialization (IS) of the population in each stream was measured by averaging individuals' PS values, where high IS values indicated low individual specialization (Bolnick et al., 2002). This metric is based on the comparison between the relative niche breadth of individuals and the niche breadth of the population.

The second metric of individual specialization was based on the population niche decomposition (TNW - Total Niche Width) into components within (WIC) and between individuals (BIC); thus, the total niche of the population results from the sum of these two components (TNW = WIC + BIC; Roughgarden, 1972; Bolnick et al., 2003). The WIC / TNW ratio represents the proportion of the niche that is attributed to the individual's niche breadth. Values close to 1 indicate that individuals use the full range of the population's niche, while lower values indicate smaller niche breadth by individuals and more considerable inter-individual differentiation, i.e., greater individual specialization.

Both individual specialization metrics (IS and WIC / TNW ratio) were calculated using the proportion of food items (highest resolution diet matrix) consumed by individuals in each stream. We used the RInSp package (Zaccarelli et al., 2013) in $\mathrm{R}$ software ( $\mathrm{R}$ Development Core Team, 2018).

\subsection{Environmental variables}

We described the streams environmental characteristics at different spatial scales in order to include as many as possible variables to accurately describe the environmental gradient. We measured chlorophyll-a concentration (1) by collecting water samples in the middle of the stream reach. We filtered water samples in the field, and later we estimated chlorophyll-a concentration in the laboratory (Golterman et al., 1978). We described physical habitat structure in nine transects, positioned at every 10 meters within the sample reach, where we obtained: depth (2), measured with a depth gauge (five equidistant measurements from one edge to the other); flow velocity (3) with a mechanical flow meter in the middle of each transect; substrate composition (4) that was visually estimated as the percentage of the bottom at one meter downstream and upstream of the transect that was covered by hard substrate (boulders, cobbles 
and pebbles); percentage of the leaf litter storage in the channel (5); and local riparian forest quality, assessed by two descriptors, forest width (6) visually assessed over both banks and riparian shading (7) that was estimated by quantifying the proportion of elements from the vegetation (canopy, leaf, branches or stems) in canopy pictures taken in every transect (Gonsamo et al., 2013). Landscape variables included the catchment area (8), calculated as the total drainage area from each stream reach, altitude (9), catchment mean slope (10) and the percentage of native vegetation cover in the whole catchment (11) and for a $100 \mathrm{~m} \mathrm{(12)} \mathrm{and} 500 \mathrm{~m}$ (13) of a semicircular buffer covering the area upstream from the sampled site (see Barbosa et al., 2019). We used high-resolution images (5-m pixel resolution) from RapidEye satellite (referring to years 2011, 2012 and 2013) to obtain the percentage of native cover. Remote sensing procedures and images processing details are described in Borges et al. (2015) and Barbosa et al. (2019).

\subsection{Data analysis}

We performed a multiple linear regression analysis to evaluate if the number of food items consumed (log-transformed) by populations was associated with the environmental predictors. We also performed a Redundancy Analysis (RDA) (Legendre \& Legendre, 2012) to evaluate the association between environmental variables and the diet composition of the populations of $K$. chapadae (question 1). In this case, we used the Feeding Index considering grouped food items (terrestrial invertebrates, aquatic invertebrates, vegetal matter, algae, and detritus) as the response variable and environmental variables as the predictors. To evaluate whether the variation in individual specialization among populations could be predicted by the set of environmental variables (question 2), we used multiple linear regression models, in which the individual specialization metrics (IS and WIC / TNW) were the response variables and the environmental variables were the predictors. We performed all analysis by using the vegan (Oksanen et al., 2020), RInSp (Zaccarelli et al., 2013) packages from $\mathrm{R}$ software (R Development Core Team, 2018).

Prior to the analysis, we evaluated the collinearity of the predictor variables by using the Variance Inflation Factor (VIF), calculated with usdm package vIFor function (Naimi et al., 2014), with a correlation cutoff between the variables equal to 0.5 . Among the set of predictors three collinear variables (500 m buffer native vegetation, flow velocity and slope) were eliminated and the following non-collinear variables were used in the models: depth, shading, consolidated substrate, leaf litter, forest width, chlorophyll-a, native vegetation in the catchment, native vegetation in the $100 \mathrm{~m}$ buffer, catchment area, and altitude.

\section{Results}

\subsection{Inter-populational variation in the diet of Knodus chapadae}

The diet of Knodus chapadae populations was composed by a wide variety of food items (mean of 12.4 food items consumed per population, ranging from five to 17) (Table 1). The number of food items consumed by populations varied significantly according to the environmental predictors $(\mathrm{p}=0.04$; $\left.\mathrm{R}^{2}{ }_{\mathrm{adj}}=0.35\right)$, but only the variable native vegetation of the catchment had a significant $(t=3.02$; $\mathrm{p}<0.01)$ partial effect in the full model, indicating that populations of streams with higher amount of native vegetation in the catchment consumed higher number of food items.

The diet composition of $K$. chapadae included terrestrial and aquatic invertebrates (mainly insects), vegetal matter, and detritus (Figure 2 and Table 1). The importance of these items varied among streams, but overall, there was a predominance of aquatic $($ mean $=49 \%)$ and terrestrial invertebrates $($ mean $=27 \%)($ Figure 2$)$. In two streams, detritus was the dominant item in the individuals' diet (greater than $75 \%$ ), and, in other two streams, vegetal matter was well represented (about 50\%).

The grouped diet of Knodus chapadae measured with Feeding Index for the population level varied significantly according to the environmental predictors $\left(\mathrm{p}=0.03 ; \mathrm{R}_{\text {adj }}^{2}=0.20\right)$, indicating that the stream environmental variables can partially predict the species' diet. The importance of terrestrial invertebrates in the diet was positively associated with shading and riparian forest width and a diet based on the vegetal matter was associated with the presence of leaf litter. Moreover, detritus was more important for individuals living in streams with higher chlorophyll-a concentration and less riparian vegetation. Finally, streams with higher catchment area and depth were associated with higher consumption of aquatic invertebrates (Figure 3).

\subsection{Individual specialization}

Individuals of Knodus chapadae consumed in mean 3.7 food items (ranging from one to eight). 
Table 1. Feeding index based on detailed diet matrix of Knodus chapadae populations across sampled streams. Autochthonous insects: larvae of Diptera (Dipt), Ephemeroptera (Ephe), Odonata (Odon), Trichoptera (Tric), Plecoptera (Plec), Megaloptera (Mega), fragments of aquatic insects (Frag), and vegetal matter (Vege); Allochthonous invertebrates: adults of Coleoptera (Cole), Hymenoptera (Hyme), Diptera (Dipt), Ensifera (Ensi), Hemiptera (Hemi), psocoptera (Pso), Lepidoptera (Lepi), Pseudoscorpiones (Pseu), and fragments of terrestrial invertebrates (Frag); Nonidentified items (NI).

\begin{tabular}{|c|c|c|c|c|c|c|c|c|c|c|c|c|c|c|c|c|c|c|c|c|}
\hline \multirow[b]{2}{*}{ 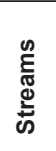 } & \multicolumn{7}{|c|}{ Aquatic invertebrates } & \multirow[b]{2}{*}{$\begin{array}{l}\stackrel{0}{\pi} \\
\frac{\pi}{4}\end{array}$} & \multirow[b]{2}{*}{$\stackrel{\mathscr{g}}{\stackrel{\Xi}{J}}$} & \multirow[b]{2}{*}{ 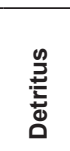 } & \multicolumn{9}{|c|}{ Terrestrial invertebrates } & \multirow[b]{2}{*}{$\overline{\mathbf{z}}$} \\
\hline & $\frac{\overrightarrow{0}}{\bar{a}}$ & $\begin{array}{l}\frac{0}{2} \\
\frac{2}{4}\end{array}$ & 흥 & $\stackrel{0}{\stackrel{0}{*}}$ & $\frac{\Xi}{0}$ & 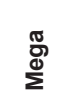 & $\begin{array}{l}\text { gूँ } \\
\text { 吾 }\end{array}$ & & & & $\frac{0}{0}$ & 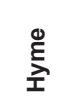 & $\stackrel{\underline{2}}{\bar{a}}$ & $\begin{array}{l}\overline{\bar{w}} \\
\text { 岌 }\end{array}$ & $\begin{array}{l}\overline{\bar{\varepsilon}} \\
\stackrel{\bar{\Phi}}{I}\end{array}$ & '̄ò & ஜ & 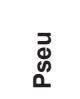 & $\begin{array}{l}\text { 刃ु } \\
\text { 胥 }\end{array}$ & \\
\hline $\mathrm{S} 1$ & & & & & & & 0.46 & 0.05 & 0.36 & & & & & & & & & & 0.13 & \\
\hline $\mathrm{S} 2$ & & & & & & & 0.50 & & 0.50 & & & & & & & & & & & \\
\hline S3 & & & & & & & 0.25 & & 0.55 & & & & & & 0.01 & & & & 0.19 & \\
\hline S4 & & & & & & & & & 0.25 & 0.04 & & 0.43 & & & & & & & 0.29 & \\
\hline S5 & & & & & & & 0.61 & 0.20 & 0.08 & & & 0.07 & & & 0.02 & & & & & 0.02 \\
\hline s6 & & & & & & 0.01 & & & & & & & 0.01 & & & & & 0.97 & & \\
\hline S7 & 0.03 & & & & & & 0.37 & & & & & 0.14 & & & & & 0.01 & & 0.08 & 0.37 \\
\hline S8 & & & & & & & 0.72 & & 0.09 & & & & & & & & & & 0.19 & \\
\hline s9 & & & & & & & 0.67 & 0.04 & 0.19 & & 0.02 & & & 0.02 & 0.04 & 0.02 & & & & \\
\hline S10 & & & & 0.01 & & & 0.39 & & 0.23 & 0.09 & & & & & & & & & 0.21 & 0.06 \\
\hline S11 & & & & & & & 0.24 & & 0.31 & & & & & & & & & & 0.45 & \\
\hline $\mathrm{S} 12$ & & & & & & & 0.33 & 0.02 & 0.17 & & & & & & & & & 0.10 & 0.37 & \\
\hline $\mathrm{S} 13$ & & & & & & & 0.81 & & & & & & & & & & 0.04 & 0.01 & 0.14 & \\
\hline S14 & & & & & & & 0.49 & & 0.12 & & & 0.16 & & & 0.01 & & & & 0.22 & \\
\hline S15 & & & 0.01 & & & & 0.86 & & & & & 0.04 & & & & & & & 0.09 & \\
\hline S16 & & & 0.09 & & & & 0.22 & & 0.17 & & & & & & & & & & 0.52 & \\
\hline S17 & & & & & & & 0.91 & & 0.09 & & & & & & & & & & & \\
\hline $\mathrm{S} 18$ & & & 0.06 & & & & 0.58 & 0.09 & 0.13 & & & & & & & & 0.01 & 0.13 & & \\
\hline S19 & & & & & 0.02 & & & & & & & & & & & & & 0.98 & & \\
\hline S20 & & & & & & & 0.11 & & 0.33 & & & & & & & & & 0.01 & 0.55 & \\
\hline S21 & & & & & & & 0.55 & & & & & & & & & 0.01 & & & 0.44 & \\
\hline S22 & & & & & & & 0.45 & & 0.11 & & & & & & & & & 0.02 & 0.41 & \\
\hline $\mathrm{S} 23$ & & 0.01 & & & & & 0.31 & & 0.45 & & & & & & & & & & 0.23 & \\
\hline S24 & & & & & & & 0.85 & & & & & & & & & & & & 0.15 & \\
\hline S25 & & & & & & & 0.89 & & & & & & & & & 0.02 & & & 0.09 & \\
\hline S26 & & & & & & & 0.31 & & 0.37 & & & & & & & & & & 0.31 & \\
\hline S27 & & & & & & 0.26 & & & 0.26 & & & & & 0.03 & 0.46 & & & & & \\
\hline S28 & & & & & & 0.24 & & & 0.61 & & & & & & 0.12 & & 0.03 & & & \\
\hline S29 & & & 0.05 & & & & 0.39 & & 0.08 & & & & & & & & & & 0.48 & \\
\hline
\end{tabular}

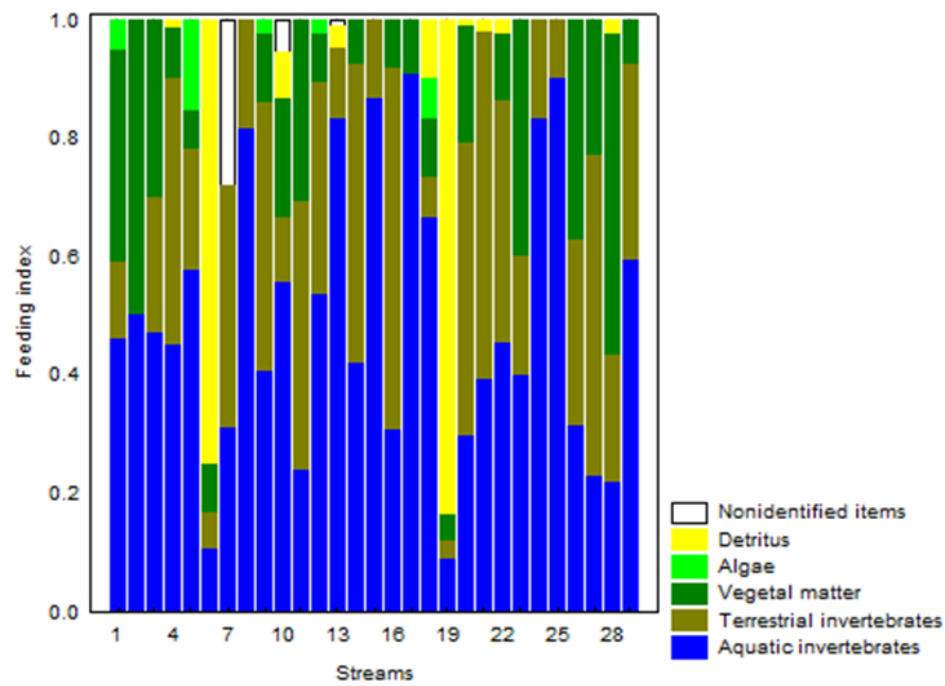

Figure 2. Feeding Index (IA) of Knodus chapadae across sampled streams in the Santa Teresa drainage, Goiás, Brazil. 


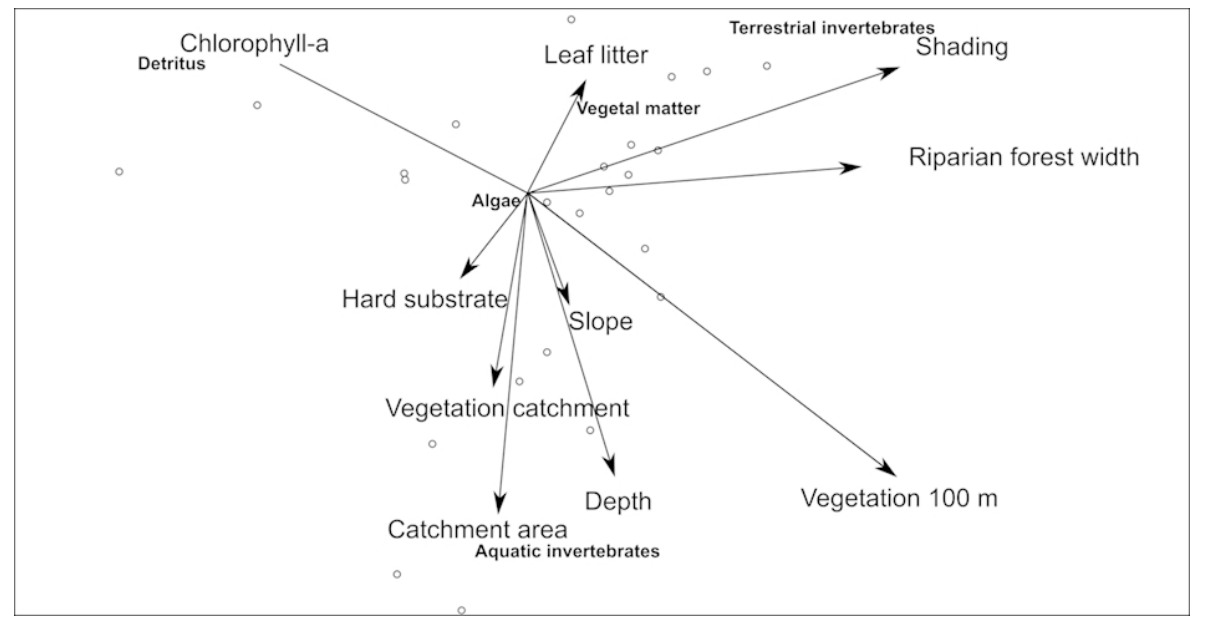

Figure 3. Biplot of the Redundancy Analysis (RDA) between the trophic structure of the Knodus chapadae populations and the environmental variables.
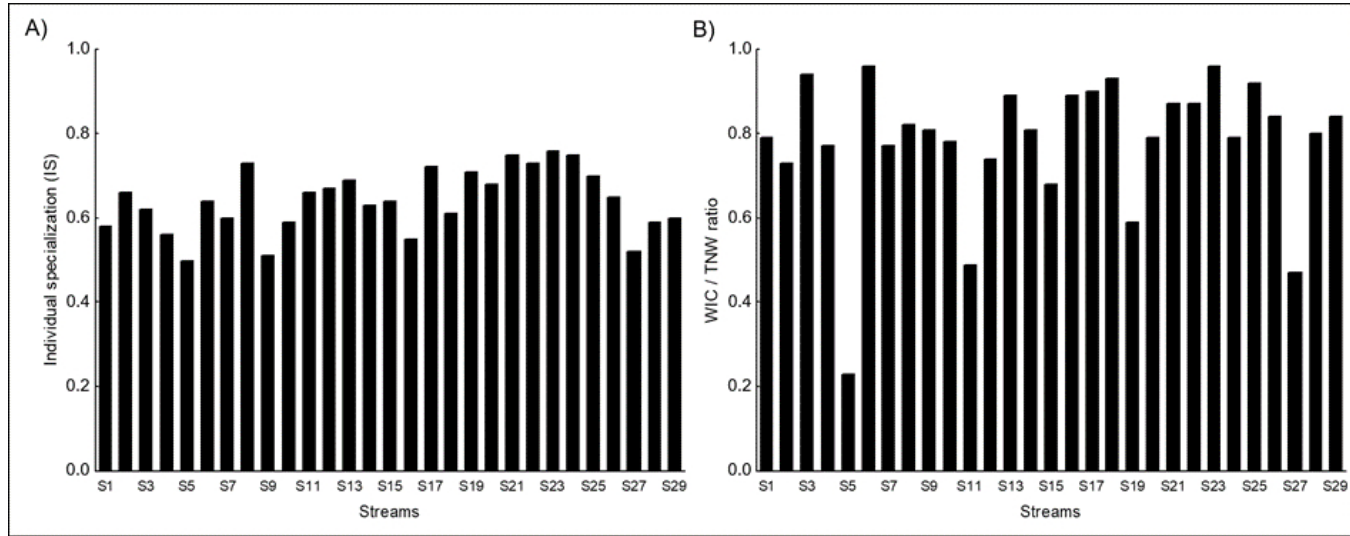

Figure 4. Individual specialization for Knodus chapadae in the different streams measured as (A) Individual Specialization Index (IS) and (B) WIC / TNW ratio that express the ratio between the average of individual niche widths (WIC) with the total niche width (TNW).

Most of $K$. chapadae populations had individuals with low individual specialization (IS: $0.64 \pm 0.07$, ranging from 0.50 to 0.73 ; WIC/TNW: $0.78 \pm 0.16$, ranging from 0.23 to 0.96 ) (Figure 4). Only one stream had a low value in the individual specialization index (0.23 for WIC / TNW), indicating greater individual specialization. For both metrics, multiple regression analysis showed that stream environmental conditions were not able to predict variation in individual specialization ( $\mathrm{p}>0.17)$.

\section{Discussion}

We studied the trophic ecology of Knodus chapadae, one of the most abundant and widespread fish in streams of the Araguaia-Tocantins ecoregion (Barbosa et al., 2019). The species diet was composed by a high diversity of food items with the dominance of allochthonous and autochthonous invertebrates (mainly insects), revealing an omnivorous diet with a tendency to insectivory. According to our results, the occurrence of the species in streams with different environmental conditions is followed by changes in its diet, probably reflecting the shift in food resource availability. However, the individual specialization was low and its variability across populations was not predictable along the environmental gradient. Together these results suggest that Knodus chapadae populations fed on by different food resources along the environmental gradient, that are similarly exploited by individuals within each population.

Characidae species are known by their trophic opportunism and phenotypic plasticity (Rezende \& Mazzoni, 2003; Ceneviva-Bastos \& Casatti, 2007). Knodus chapadae follows the Characidae family pattern, representing a generalist and 
opportunist species with flexibility in the use of different food resources. The opportunism and flexibility are reinforced by the diet-environment relationship at the populational level, supporting our first hypothesis. Allochthonous invertebrates and vegetal organic matter were important in the species' diet, especially in more conserved streams (i.e., streams with shaded channel and with more extensive riparian forest). In fact, the availability of allochthonous items increases with the presence of more conserved riparian vegetation (Barili et al., 2011; Cardoso \& Couceiro, 2017; Tonin et al., 2017). On the other hand, riparian forest removal provides significant changes in stream food items input, including dramatic reduction of allochthonous items usually used as food items itself (terrestrial invertebrates, leaves, fruits, flowers) or as feeding site (e.g., trunks and litter) (Fausch \& Northcote, 1992; Lorion \& Kennedy, 2009). The forest cover absence increases the sunlight incidence favoring both algae proliferation (Lorion \& Kennedy, 2009) and marginal herbaceous vegetation, consisting mainly of exotic grasses (Casatti et al., 2009). In these streams, the decomposition of the submerged roots and leaves from grasses can increase the amount of organic matter and the detritus retention (Menninger \& Palmer, 2007; Rocha et al. 2009). In our study, these processes are suggested by the higher concentration of chlorophyll-a in deforested streams where Knodus chapadae populations exhibit a more detritivore diet. Furthermore, populations living in streams with larger catchment area and greater depth have a diet with a higher contribution of aquatic invertebrates. These environmental variables are positively associated with water flow that, in turn, enhances the supply of drifted invertebrates, such as larvae of aquatic insects (Brittain \& Eikeland, 1988; Hughes \& Dill, 1990).

Populations of conserved streams (with higher amount of native vegetation in the catchment) consumed a higher number of food items. This result is in accordance with our expectation that most conserved streams would offer greater diversity of food. According to ecological opportunity hypothesis, the greater diversity of resources can offer an opportunity for niche segregation between individuals. However, differently from the expected, $K$. chapadae individuals exhibited a wide niche with great overlapping between them, as shown by the low individual specialization in the most of populations. This result does not corroborate the idea of 'population generalist, individual specialist'
(Smith et al. 2011). Knodus species actively swim in the water column, feeding on drifting items (mainly insects) (Ceneviva-Bastos \& Casatti, 2007). Drift insects consumed by nektonic stream fishes are represented by benthic aquatic larvae released from the bottom and terrestrial and flying organisms that fallen into the water (Costa-Pereira et al., 2017). Thus, it is possible that the similar diet among individuals in a given site reflects the opportunism in catch these drift items even in streams with different environmental conditions. If these drift food items are abundant enough to supply the needs of the fish population, the relaxed competition would favor that organisms feed on preferable food resources (e.g. drift insects) resulting in the convergence of the diet (Emlen, 1966; Schoener, 1971). We do not have available data on population density and food resources availability, so that the role of density-dependent mechanisms driving the intra-populational patterns $K$. chapadae niche would require further investigation.

Despite we do not observed individual specialization in the trophic niche of $K$. chapadae, it is worth to consider that the trophic specialization may occur in other niche dimensions, such habitat use (Navarro et al., 2017). In fact, studies carried out with congeneric species, like $K$. moenkhausii, show that, despite these fishes occupy predominantly the middle of water column of sites with intermediate water current (Ceneviva-Bastos et al., 2010), they can also explore other microhobitats (marginal vegetation and the bottom) in a variety of mesohabitats (runs, riffles and pools) (CenevivaBastos \& Casatti, 2007). However, there is no information if these individuals specialize in determined micro or mesohabitat. Studying the Eurasian perch (Perca fluviatilis L.) in lakes, Quevedo et al. (2009) found an interaction between trophic niche specialization and habitat use. Individuals from littoral subpopulation exhibited higher individual specialization, while the ones from pelagic subpopulation living in a less diverse environment had more generalist individuals. Knodus populations tend to be more abundant in runs, but their individuals also occupy pools and riffles (Ceneviva-Bastos et al., 2010; Teresa et al., 2016). As our populations of Knodus chapadae comprised individuals captured over reaches of 80 meters in each stream, which includes different micro and mesohabitats (riffle, pool and runs), observed patterns in these streams may have been more influenced by subpopulations from runs. Thus, we may have underestimated the 
different patterns that could emerge from pooldwelling individuals that would be exposed to greater variability in food resources usually found in this mesohabitat (Angermeier \& Karr, 1984; Berkman \& Rabeni, 1987). If these possible intrapopulational mechanisms of habitat and trophic niche partition observed in other species and ecosystems (Quevedo et al., 2009; Navarro et al., 2017) may be applied for tetra fishes in streams is an interesting topic of future research that remains to be tested.

In summary, our results indicate that Knodus chapadae has a diversified diet that varies with environmental conditions. This opportunism is well documented for tetra fishes in population level. By evaluating the intra and interindividual patterns of the trophic niche of this species, our study provides support for the generalization that the feeding plasticity exhibited by tetra fishes may be a direct consequence of the opportunism manifested on the individual level.

\section{Acknowledgements}

We are grateful to the team of the Laboratório de Biogeografia e Ecologia Aquática (Bioecol) and to the UEG for the logistical support; to Fernando R. Carvalho for his assistance with the identification of species. R.C.N. was supported by undergraduate fellowship from the Conselho Nacional de Desenvolvimento Científico e Tecnológico (CNPq); P.P.B. was financed by the Coordenação de Aperfeiçoamento de Pessoal de Nível Superior - Brasil (CAPES) - Finance Code 001; J.O.Z. was supported by pos-doctoral fellowship from Fundação de Amparo à Pesquisado Estado de São Paulo (FAPESP, 2018/06033-1); F.B.T. and L.C.are supported by the Conselho Nacional de Desenvolvimento Científico e Tecnológico (CNPq) productivity fellowship (306912/2018-0 and 301877/2017-3, respectively). This paper was developed in the context of National Institutes for Science and Technology (INCT) in Ecology, Evolution and Biodiversity Conservation, supported by MCTIC/CNPq (proc. 465610/2014-5), CNPq (proc. 482185/2012-0), FAPEG (proc. 201210267000703 and AUXPE 2036/2013).

\section{References}

ABELL, R., THIEME, M.L., REVENGA, C., BRYER, M., KOTTELAT, M., BOGUTSKAYA, N., COAD, B., MANDRAK, N., BALDERAS, S.C., BUSSING, W., STIASSNY, M.L.J., SKELTON, P., ALLEN, G.R., UNMACK, P., NASEKA,
A., NG, R., SINDORF, N., ROBERTSON, J., ARMIJO, E., HIGGINS, J.V., HEIBEL, T.J., WIKRAMANAYAKE, E., OLSON, D., LÓPEZ, H.L., REIS, R.E., LUNDBERG, J.G., SABAJ PÉREZ, M.H. and PETRY, P. Freshwater ecoregions of the world: a new map of biogeographic units for freshwater biodiversity conservation. Bioscience, 2008, 58(5), 403-414. http://dx.doi.org/10.1641/ B580507.

ANGERMEIER, P.L. and KARR, J.R. Relationships between woody debris and fish habitat in a small warmwater stream. Transactions of the American Fisheries Society, 1984, 113(6), 716-726. http:// dx.doi.org/10.1577/1548-8659(1984)113<716:RB WDAF>2.0.CO;2.

ARAÚJO, M.S., BOLNICK, D.I. and LAYMAN, C.A. The ecological causes of individual specialization. Ecology Letters, 2011, 14(9), 948-958. http:// dx.doi.org/10.1111/j.1461-0248.2011.01662.x. PMid:21790933.

BARBOSA, H.O., BORGES, P.P., DALA-CORTE, R.B., MARTINS, P.T.A. and TERESA, F.B. Relative importance of local and landscape variables on fish assemblages in streams of Brazilian savanna. Fisheries Management and Ecology, 2019, 26(2), 119-130. http://dx.doi.org/10.1111/fme.12331.

BARILI, E., AGOSTINHO, A.A., GOMES, L.C. and LATINI, J.D. The coexistence of fish species in streams: relationships between assemblage attributes and trophic and environmental variables. Environmental Biology of Fishes, 2011, 92(1), 41-52. http://dx.doi.org/10.1007/s10641-011-9814-2.

BERKMAN, H.E. and RABENI, C.F. Effect of siltation on stream fish communities. Environmental Biology of Fishes, 1987, 18(4), 285-294. http://dx.doi. org/10.1007/BF00004881.

BOJSEN, B.H. Diet and condition of three fish species (Characidae) of the Andean foothills in relation to deforestation. Environmental Biology of Fishes, 2005, 73(1), 61-73. http://dx.doi.org/10.1007/s10641004-5330-y.

BOLNICK, D.I., AMARASEKARE, P., ARAÚJO, M.S., BÜRGER, R., LEVINE, J.M., NOVAK, M., RUDOLF, V.H., SCHREIBER, S.J., URBAN, M.C. and VASSEUR, D.A. Why intraspecific trait variation matters in community ecology. Trends in Ecology \& Evolution, 2011, 26(4), 183-192. http://dx.doi.org/10.1016/j.tree.2011.01.009. PMid:21367482.

BOLNICK, D.I., SVANBÄCK, R., FORDYCE, J.A., YANG, L.H., DAVIS, J.M., HULSEY, C.D. and FORISTER, M.L. The ecology of individuals: incidence and implications of individual specialization. American Naturalist, 2003, 161(1), 1-28. http://dx.doi.org/10.1086/343878. PMid:12650459. 
BOLNICK, D.I., YANG, L.H., FORDYCE, J.A., DAVIS, J.M. and SVANBÄCK, R. Measuring individual-level resource specialization. Ecology, 2002, 83(10), 2936-2941. http://dx.doi.org/10.1890/00129658(2002)083[2936:MILRS]2.0.CO;2.

BORGES, P.P., MARTINS, P.T.A. and FERREIRA, A.A. Uso e ocupação do solo por meio de uma série histórica na bacia do rio Santa Teresa em Goiás. Revista Brasileira de Geografia Física, 2016, 9(1), 296-304. http://dx.doi.org/10.26848/rbgf. v9.1.p296-304.

BORGES, P.P., TERESA, F.B., MARTINS, P.T.A. and NABOUT, J.C. Relative influence of direct and indirect environmental effects on sestonic chlorophyll-a concentration in Cerrado streams. Acta Limnologica Brasiliensia, 2015, 27(3), 301-310. http://dx.doi.org/10.1590/S2179-975X1815.

BRITTAIN, J.E. and EIKELAND, T.J. Invertebrate drift - A review. Hydrobiologia, 1988, 166(1), 77-93. http://dx.doi.org/10.1007/BF00017485.

BUSTAMANTE, M.M.C., NARDOTO, G.B., PINTO, A.S., RESENDE, J.C.F., TAKAHASHI, F.S.C. and VIEIRA, L.C.G. Potential impacts of climate change on biogeochemical functioning of Cerrado ecosystems. Brazilian Journal of Biology $=$ Revista Brasileira de Biologia, 2012, 72(3), 655-671. Supplement. http://dx.doi.org/10.1590/S151969842012000400005. PMid:23011296.

CARDOSO, A.C. and COUCEIRO, S.R.M. Insects in the diet of fish from Amazonian streams, in western Pará, Brazil. Marine and Freshwater Research, 2017, 68(11), 2052-2060. http://dx.doi.org/10.1071/ MF16173.

CASATTI, L., DE PAUlA FERREIRA, C. and CARVALHO, F.R. Grass-dominated stream sites exhibit low fish species diversity and dominance by guppies: an assessment of two tropical pasture river basins. Hydrobiologia, 2009, 632(1), 273-283. http:// dx.doi.org/10.1007/s10750-009-9849-y.

CENEVIVA-BASTOS, M. and CASATTI, L. Oportunismo alimentar de Knodus moenkhausii (Teleostei, Characidae): uma espécie abundante em riachos do noroeste do Estado de São Paulo, Brasil. Iheringia. Série Zoologia, 2007, 97(1), 7-15. http:// dx.doi.org/10.1590/S0073-47212007000100002.

CENEVIVA-BASTOS, M., CASATTI, L. and ROSSAFERES, D.C. Meso and micro-habitat analysis and feeding habits of small nektonic characins (Teleostei: Characiformes) in Neotropical streams. Revista Brasileira de Zoologia, 2010, 27(2), 191-200. http:// dx.doi.org/10.1590/S1984-46702010000200006.

CENEVIVA-BASTOS, M., MONTAÑA, C.G., SCHALK, C.M., CAMARGO, P.B. and CASATTI, L. Responses of aquatic food webs to the addition of structural complexity and basal resource diversity in degraded Neotropical streams. Austral Ecology,
2017, 42(8), 908-919. http://dx.doi.org/10.1111/ aec. 12518 .

CHAN, E.K.W., ZHANG, Y. and DUDGEON, D. Arthropod 'rain' into tropical streams: the importance of intact riparian forest and influences of fish diets. Marine and Freshwater Research, 2008, 59(8), 653660. http://dx.doi.org/10.1071/MF07191.

COSTA-PEREIRA, R., TAVARES, L.E.R., DE CAMARGO, P.B. and ARAÚJO, M.S. Seasonal population and individual niche dynamics in a tetra fish in the Pantanal wetlands. Biotropica, 2017, 49(4), 531-538. http://dx.doi.org/10.1111/btp.12434.

CUNHA, A.F., WOLFF, L.L. and HAHN, N.S. Seasonal changes at population and individual levels in the diet of juvenile catfish in a Neotropical floodplain. Journal of Freshwater Ecology, 2018, 33(1), 274-284. http:// dx.doi.org/10.1080/02705060.2018.1442371.

DARIMONT, C.T., PAQUET, P.C. and REIMCHEN, T.E. Landscape heterogeneity and marine subsidy generate extensive intrapopulation niche diversity in a large terrestrial vertebrate. The Journal of Animal Ecology, 2009, 78(1), 126-133. http:// dx.doi.org/10.1111/j.1365-2656.2008.01473.x. PMid:19120600.

EMLEN, J.M. The role of time and energy in food preference. American Naturalist, 1966, 100(916), 611-617. http://dx.doi.org/10.1086/282455.

FAUSCH, K.D. and NORTHCOTE, T.G. Large woody debris and salmonid habitat in a small coastal British Columbia stream. Canadian Journal of Fisheries and Aquatic Sciences, 1992, 49(4), 682-693. http://dx.doi. org/10.1139/f92-077.

FERREIRA, A., GERHARD, P. and CYRINO, J.E.P. Diet of Astyanax paranae (Characidae) in streams with different riparian land covers in the Passa-Cinco River basin, southeastern Brazil. Iheringia. Série Zoologia, 2012, 102(1), 80-87. http://dx.doi.org/10.1590/ S0073-47212012000100011.

FLORES, L., LARRANAGA, A., DÍEZ, J. and ELOSEGI, A. Experimental wood addition in streams: effects on organic matter storage and breakdown. Freshwater Biology, 2011, 56(10), 2156-2167. http://dx.doi.org/10.1111/j.13652427.2011.02643.x.

GELWICK, F.P. and MCINTYRE, P.B. Trophic relations of stream fishes. In: F.R. HAUER and G. LAMBERTI, editors. Methods in stream ecology. 3rd ed. Cambridge: Academic Press, 2017, pp. 457-479, vol. 1: Ecosystem structure. http://dx.doi org/10.1016/B978-0-12-416558-8.00022-6.

GOLTERMAN, H.L., CLYMO, R.S. and OHNSTAD, M.A. Methods for physical and chemical analysis of fresh water. 2nd ed. Oxford: Blackwell Scientific Publications, 1978.

GONÇALVES, C.S., BRAGA, F.M.S. and CASATTI, L. Trophic structure of coastal freshwater stream 
fishes from an Atlantic rainforest: evidence of the importance of protected and forest-covered areas to fish diet. Environmental Biology of Fishes, 2018, 101(6), 933-948. http://dx.doi.org/10.1007/s10641018-0749-8.

GONSAMO, A., D'ODORICO, P. and PELLIKKA, P. Measuring fractional forest canopy element cover and openness - definitions and methodologies revisited. Oikos, 2013, 122(9), 1283-1291. http://dx.doi. org/10.1111/j.1600-0706.2013.00369.x.

HUGHES, N.F. and DILL, L.M. Position choice by drift-feeding salmonids: model and test for Arctic grayling (Thymallus arcticus) in subarctic mountain streams, interior Alaska. Canadian Journal of Fisheries and Aquatic Sciences, 1990, 47(10), 2039-2048. http://dx.doi.org/10.1139/f90-228.

KAWAKAMI, E. and VAZZOLER, G. Método gráfico e estimativa de índice alimentar aplicado no estudo de alimentação de peixes. Boletim do Instituto Oceanográfico, 1980, 29(2), 205-207. http://dx.doi. org/10.1590/S0373-55241980000200043.

LEAL, C.G., POMPEU, P.S., GARDNER, T.A., LEITÁO, R.P., HUGHES, R.M., KAUFMANN, P.R., ZUANON, J., DE PAULA, F.R., FERRAZ, S.F.B., THOMSON, J.R., MAC NALLY, R., FERREIRA, J. and BARLOW, J. Multi-scale assessment of human-induced changes to Amazonian instream habitats. Landscape Ecology, 2016, 31(8), 1725-1745. http://dx.doi.org/10.1007/s10980016-0358-x.

LEGENDRE, P. and LEGENDRE, L. Numerical ecology. 3rd ed. Amsterdam: Elsevier, 2012.

LIANG, D., YANG, S., PAGANI-NÚNEEZ, E., HE, C., LIU, Y., GOODALE, E., LIAO, W.B. and HU, J. How to become a generalist species? Individual niche variation across habitat transformation gradients. Frontiers in Ecology and Evolution, 2020, 8, 597450. http://dx.doi.org/10.3389/fevo.2020.597450.

LORION, C.M. and KENNEDY, B.P. Riparian forest buffers mitigate the effects of deforestation on fish assemblages in tropical headwater streams. Ecological Applications, 2009, 19(2), 468-479. http://dx.doi. org/10.1890/08-0050.1. PMid:19323203.

LOWE-MCCONNELL, R.H. Ecological studies in tropical fish communities. Cambridge: Cambridge University Press, 1987. http://dx.doi.org/10.1017/ CBO9780511721892.

MANNA, L.R., VILLÉGER, S., REZENDE, C.F. and MAZZONI, R. High intraspecific variability in morphology and diet in tropical stream fish communities. Ecology Freshwater Fish, 2019, 28(1), 41-52. http://dx.doi.org/10.1111/eff.12425.

MAZZONI, R., FENERICH-VERANI, N. and CARAMASCHI, E.P. Electrofishing as a sampling technique for coastal stream fish populations and communities in the Southeast of Brazil. Revista brasileira de biologia, 2000, 60(2), 205-216. http:// dx.doi.org/10.1590/S0034-71082000000200003. PMid:10959103.

MENNINGER, H.L. and PALMER, M.A. Herbs and grasses as an allochthonous resource in open-canopy headwater streams. Freshwater Biology, 2007, 52(9), 1689-1699. http://dx.doi.org/10.1111/j.13652427.2007.01797.x.

MORTILlARO, J.M., POUILLY, M., WACH, M., FREITAS, C.E.C., ABRIL, G. and MEZIANE, T. Trophic opportunism of central Amazon floodplain fish. Freshwater Biology, 2015, 60(8), 1659-1670. http://dx.doi.org/10.1111/fwb.12598.

MUGNAI, R., NESSIMIAN, J.L. and BAPTISTA, D.F. Manual de identificação de macroinvertebrados aquáticos do Estado do Rio de Janeiro: para atividades técnicas, de ensino e treinamento em programas de avaliação da qualidade ecológica dos ecossistemas lóticos. Rio de Janeiro: Technical Books Editora, 2010.

MURRAY, I.W. and WOLF, B.O. Desert tortoise (Gopherus agassizii) dietary specialization decreases across a precipitation gradient. PLoS One, 2013, 8(6), e66505. http://dx.doi.org/10.1371/journal. pone.0066505. PMid:23840495.

NAIMI, B., HAMM, N.A.S., GROEN, T.A., SKIDMORE, A.K. and TOXOPEUS, A.G. Where is positional uncertainty a problem for species distribution modelling? Ecography, 2014, 37(2), 191-203. http://dx.doi.org/10.1111/j.16000587.2013.00205.x.

NAVARRO, J., GRÉMILLET, D., RAMIREZ, F.J., AFÁN, I., BOUTEN, W. and FORERO, M.G. Shifting individual habitat specialization of a successful predator living in anthropogenic landscapes. Marine Ecology Progress Series, 2017, 578, 243-251. http://dx.doi.org/10.3354/meps12124.

OKSANEN, J., BLANCHET, F.G., FRIENDLY, M., KINDT, R., LEGENDRE, P., MCGLINN, D., MINCHIN, P.R., O'HARA, R.B., SIMPSON, G.L., SOLYMOS, P., STEVENS, M.H.H., SZOECS, E. and WAGNER, H. vegan: Community ecology package. $R$ package version 2.5-7. Vienna, Austria: R Foundation for Statistical Computing, 2020.

QUEVEDO, M., SVANBÄCK, R. and EKLÖV, P. Intrapopulation niche partitioning in a generalist predator limits food web connectivity. Ecology, 2009, 90(8), 2263-2274. http://dx.doi.org/10.1890/071580.1. PMid:19739388.

R DEVELOPMENT CORE TEAM. $R$ : a language and environment for statistical computing [online]. Vienna, Austria: R Foundation for Statistical Computing, 2018 [viewed 16 Mar. 2021]. Available from: https:// www.R-project.org/

REZENDE, C.F. and MAZZONI, R. Aspectos da alimentação de Bryconamericus microcephalus 
(Characiformes, Tetragonopterinae) no Córrego Andorinha, Ilha Grande-RJ. Biota Neotropica, 2003, 3(1), 1-6. http://dx.doi.org/10.1590/S167606032003000100012 .

ROCHA, F.C.D., CASATTI, L., CARVALHO, F.R. and SILVA, A.M.D. Fish assemblages in stream stretches occupied by cattail (Typhaceae, Angiospermae) stands in Southeast Brazil. Neotropical Ichthyology, 2009, 7(2), 241-250. http://dx.doi.org/10.1590/S167962252009000200016

ROUGHGARDEN, J. Evolution of niche width. American Naturalist, 1972, 106(952), 683-718. http://dx.doi.org/10.1086/282807.

SCHOENER, T.W. Theory of feeding strategies. Annual Review of Ecology and Systematics, 1971, 2(1), 369-404. http://dx.doi.org/10.1146/annurev. es.02.110171.002101.

SMITH, J.A., BAUMGARTNER, L.J., SUTHERS, I.M. and TAYLOR, M.D. Generalist niche, specialist strategy: the diet of an Australian percichthyid. Journal of Fish Biology, 2011, 78(4), 1183-1199. http:// dx.doi.org/10.1111/j.1095-8649.2011.02926.x. PMid:21463314.

STRAHLER, A.N. Quantitative analysis of watershed geomorphology. Transactions - American Geophysical Union, 1957, 38(6), 913-920. http://dx.doi. org/10.1029/TR038i006p00913.

SVANBÄCK, R. and BOLNICK, D.I. Intraspecific competition affects the strength of individual specialization: an optimal diet theory method. Evolutionary Ecology Research, 2005, 7, 993-1012.

SVANBÄCK, R. and BOLNICK, D.I. Intraspecific competition drives increased resource use diversity within a natural population. Proceedings. Biological Sciences, 2007, 274(1611), 839-844. http://dx.doi. org/10.1098/rspb.2006.0198. PMid:17251094.

SVANBÄCK, R. and PERSSON, L. Individual diet specialization, niche width and population dynamics: implications for trophic polymorphisms. Journal of Animal Ecology, 2004, 73(5), 973-982. http://dx.doi. org/10.1111/j.0021-8790.2004.00868.x.
TERESA, F.B., SOUZA, L.S., SILVA, D.M.A., BARBOSA, H.O., LIMA, J.D. and NABOUT, J.C. Environmental constraints structuring fish assemblages in riffles: evidences from a tropical stream. Neotropical Ichthyology, 2016, 14(3), e150185. http://dx.doi.org/10.1590/1982-022420150185.

TONIN, A.M., GONÇALVES JUNIOR, J.F., BAMBI, P., COUCEIRO, S.R.M., FEITOZA, L.A.M., FONTANA, L.E., HAMADA, N., HEPP, L.U., LEZAN-KOWALCZUK, V.G., LEITE, G.F.M., LEMES-SILVA, A.L., LISBOA, L.K., LOUREIRO, R.C., MARTINS, R.T., MEDEIROS, A.O., MORAIS, P.B., MORETTO, Y., OLIVERIA, P.C.A., PEREIRA, E.B., FERREIRA, L.P., PÉREZ, J., PETRUCIO, M.M., REIS, D.F., S REZENDE, R., ROQUE, N., SANTOS, L.E.P., SIEGLOCH, A.E., TONELLO, G. and BOYERO, L. Plant litter dynamics in the forest-stream interface: precipitation is a major control across tropical biomes. Scientific Reports, 2017,7(1), 10799. http://dx.doi.org/10.1038/ s41598-017-10576-8. PMid:28883445.

XIA, Y., LI, Y., ZHU, S., LI, J., LI, S. and LI, X. Individual dietary specialization reduces intraspecific competition, rather than feeding activity, in black amur bream (Megalobrama terminalis). Scientific Reports, 2020, 10(1), 17961. http://dx.doi.org/10.1038/ s41598-020-74997-8. PMid:33087846.

ZACCARELLI, N., BOLNICK, D.I. and MANCINELLI, G. RInSp: an $r$ package for the analysis of individual specialization in resource use. Methods in Ecology and Evolution, 2013, 4(11), 10181023. http://dx.doi.org/10.1111/2041-210X.12079.

ZENI, J.O. and CASATTI, L. The influence of habitat homogenization on the trophic structure of fish fauna in tropical streams. Hydrobiologia, 2014, 726, 259270. http://dx.doi.org/10.1007/s10750-013-1772-6.

Received: 16 March 2021 Accepted: 23 August 2021

Associate Editor: Ronaldo Angelini. 